\title{
Wykaz prac magisterskich napisanych na seminariach językoznawczych w Instytucie Filologii Polskiej UAM w roku akademickim 2009/2010
}

1. Anna Ambrozik, „Mówię, jakbym pisat", czyli o idiolekcie Bohdana Tomaszewskiego na podstawie jego relacji z Wimbledonu (prof. dr hab. Halina Zgółkowa' ${ }^{1}$.

2. Paulina B a nasiak, Pole tematyczne słownictwa odzieżowego we „Wspótczesnym słowniku języka polskiego" pod redakcja Bogustawa Dunaja (prof. dr hab. Anna Piotrowicz).

3. Anna B artnik, Językdzieci w wieku przedszkolnym. Stownictwo i sktadnia (prof. dr hab. Anna Piotrowicz).

4. Magdalena Bereźnicka, Etyka dziennikarska na podstawie tekstów Jana Pawta II (prof. dr hab. Tadeusz Zgółka).

5. Weronika Bilińska, Reklamowa erotyka $i$ ciało $w$ lingwistyczno-kulturowej perspektywie badawczej (prof. dr hab. Tadeusz Zgółka).

6. Małgorzata Błażej, Językowe strategie przekonywania $i$ niewerbalne mechanizmy perswazyjne na przyktadzie debaty przedwyborczej 2007:

${ }^{1} \mathrm{~W}$ nawiasach umieszczono nazwiska promotorów prac.
Jarosław Kaczyński - Donald Tusk (prof. dr hab. Halina Zgółkowa).

7. Iwona Borkowska, Jezzykowy obraz Rosji i Niemiec w polskich tygodnikach opinii na przykładzie ,Polityki” $i$,Newsweeka” (prof. dr hab. Halina Zgółkowa).

8. Halina Bulczyńska, Rozpoznawalność polskich przystów. Studium pragmalingwistyczne (prof. dr hab. Tadeusz Zgółka).

9. Michał Capiński, Nazwy perfum i ich pochodzenie jako przyktad wspótczesnych chrematonimów (prof. dr hab. Halina Zgółkowa).

10. Kasjana Cybal, Polszczyzna konsumpcyjna $w$ drobnych ogtoszeniach prasowych z okresu PRL-u i po transformacji. Firmonimy (prof. dr hab. Anna Piotrowicz).

11. Monika Chudy, Sposoby formułowania tytułów prasowych $w$ tygodni$k u$ „Newsweek” (prof. dr hab. Tadeusz Zgółka)

12. Łukasz Czata, Pionierzy tabloidyzacji polskich mediów, czyli analiza wzrostu infotainmentu $w$ Polsce (prof. dr hab. Halina Zgółkowa). 
13. Mirosław Dołgopoł, Stownictwo $i$ frazeologia życia towarzyskiego w miesięczniku „Playboy” (prof. dr hab. Anna Piotrowicz).

14. Anita Domagała, Jak studentka/ student ze studentka/studentem? czyli o komunikacji interpersonalnej (prof. dr hab. Tadeusz Zgółka).

15. Zuzanna Małgorzata Fogtman-Budaj, Językowe $i$ pozajęzykowe środki perswazji wreklamie internetowej (prof. dr hab. Anna Piotrowicz).

16. Agata Ge sner, Glosy w „Rozmyślaniu przemyskim”. Analiza formalna (dr Tomasz Mika).

17. Agnieszka Grygiel, Stownictwo oceniajace $w$ recenzjach ksiażkowych z tygodników: „Gazeta Polska”, ,Polityka”, ,, Wprost” (prof. dr hab. Stanisław Mikołajczak).

18. Marta Ignaczak, Stownictwo życia towarzyskiego $w$,,Wysokich Obcasach" (prof. dr hab. Anna Piotrowicz).

19. Alicja Jakubicz, Porównania $w$,Dobrym” Waldemara Eysiaka (prof. dr hab. Stanisław Mikołajczak).

20. Beata J z ziers ka, Innowacje leksykalne w polskim dyskursie prasowym na przyktadzie tygodnika ,Newsweek” (prof. dr hab. Anna Piotrowicz).

21. Agnieszka Jeziorek, Frazeologizmy połamane, czyli innowacje frazeologiczne $w$ serialu „Brzydula” (prof. dr hab. Tadeusz Zgółka).

22. Natalia Jędrzejak, Stownictwo $i$ frazeologia młodzieżowe $w$ utworach Marty Fox (prof. dr hab. Stanisław Mikołajczak).

23. Magdalena Kaczmarek, Stownictwo sprawozdania sportowego w ujeciu statystycznym (na przyktadzie meczów piłki nożnej) (prof. dr hab. Halina Zgółkowa).

24. Marta Kapczyńska, Stowa zakazane $i$ nielubiane, czyli używanie wulgaryzmów w języku polskim (prof. dr hab. Tadeusz Zgółka).

25. Barbara Kicinska, Leksyka ślubna $i$ weselna we wspótczesnej polszczyźnie (na przykładzie miesięcznika „,Moda na Ślub”) (prof. dr hab. Anna Piotrowicz).

26. Natalia Klimiuk, Językowe środki perswazji $w$ reklamach kosmetyków dla kobiet $i$ mężczyzn (na podstawie czasopism) (prof. dr hab. Anna Piotrowicz).

27. Anna Kołcon, Komizm w różnych odsłonach $w$ oparciu o teksty kabaretu Tey. Analiza językowo-stylistyczna (prof. dr hab. Stanisław Mikołajczak).

28. Ida K o now alik, Gwara studentów polskich i rosyjskich (prof. dr hab. Andrzej Sieradzki).

29. Piotr K o s ze la, Stownictwo rockowe na podstawie prasy rockowej (prof. dr hab. Stanisław Mikołajczak).

30. Katarzyna Kowalczyk, Wybrane przyimki przestrzenno-dynamiczne taczace sie z czasownikami ruchu w języku serbskim i polskim (prof. dr hab. Andrzej Sieradzki).

31. Karolina Kowalska, Obraz polszczyzny młodego pokolenia $w$ twórczości Anny Burzyńskiej (prof. dr hab. Anna Piotrowicz).

32. Karolina Kowalska, Stownictwo $z$ pola tematycznego ,koń” $w$ miesięczniku „Koński Targ. Ogólnopolska Giełda Koni Hodowlanych”. Analiza leksykalna $i$ frekwencyjna (prof. dr hab. Anna Piotrowicz).

33. Szymon Ko złow ski, Rzecz o Marcinie Rozynku (prof. dr hab. Tadeusz Zgółka).

34. Bartosz L e śn i a k, Leksyka ifrazeologia w prasie sportowej na przyktadzie „Przegladu Sportowego" i ,Sportu” (prof. dr hab. Stanisław Mikołajczak). 
35. Paulina Lewczyk, Czarno-biała retoryka języka polityków (prof. dr hab. Tadeusz Zgółka).

36. Marta Łako ma, Jak widzimy celebrytów, czyli język ciała w interpretacji Polaków i Niemców (prof. dr hab. Tadeusz Zgółka).

37. Aneta Łaszkiewicz, Język ciata $w$ komunikacji międzykulturowej (prof. dr hab. Tadeusz Zgółka).

38. Marta Maciejewska, Sposoby określania trudnych sytuacji życiowych $w$ listach dziewczyn do redakcji czasopism młodzieżowych (prof. dr hab. Stanisław Mikołajczak).

39. Anna Malisz, Konceptualizacja pojęć ,feminizm" $i$,feministka" przez uczniów szkót średnich (prof. dr hab. Andrzej Sieradzki).

40. Ewelina Mielcarek, Stowa w opisie świata. Stownictwo używane w miesięczniku ,Voyage” (prof. dr hab. Tadeusz Zgółka).

41. Magdalena Mielcarek, Antroponimy nieoficjalne jako przejaw zachowań językowych $w$ społeczeństwie wiejskim Świecy (gmina Odolanów) (prof. dr hab. Stanisław Mikołajczak).

42. Anna Migalska, Język politykówujęcie ironiczne na podstawie programu „Szkło kontaktowe”. Rozważania semantyczno-leksykalne (prof. dr hab. Halina Zgółkowa).

43. Izabela Mójta, Medialne stowa znane i nieznane odbiorcom (prof. $\mathrm{dr}$ hab. Tadeusz Zgółka).

44. Katarzyna Morawska, Frazeologizmy $i$ innowacje frazeologiczne $w$ wypowiedziach polityków (na podstawie wywiadów prasowych) (prof. $\mathrm{dr}$ hab. Anna Piotrowicz).

45. Izabela N ow ak, Jezzykowe przejawy agresji $w$ wypowiedziach polityków (prof. dr hab. Stanisław Mikołajczak).
46. Jolanta Nowak, Odchodzqce słownictwo moich czasów (prof. dr hab. Anna Piotrowicz).

47. Anna Olejniczak, Co można kupić dziecku, czyli polszczyzna konsumpcyjna $w$ czasopismach dla młodych rodziców (prof. dr hab. Anna Piotrowicz).

48. Barbara Maria P a w e le c, Historyczne nazwiska mieszkańców Poznania w XVI i XVII wieku na podstawie rejestrów czopowego z lat 1534-1634. Analiza onomastyczno-kulturowa (prof. dr hab. Irena Sarnowska-Giefing).

49. Izabela P awlak, Słownictwo życia towarzyskiego w ,Jeżycjadzie” Matgorzaty Musierowicz (na przyktadzie wybranych powieści) (prof. dr hab. Anna Piotrowicz).

50. Patrycja Pelc, „Wiadomości Literackie" $w$ poszukiwaniu czytelnika, czyli o marketingu prasowym (prof. dr hab. Tadeusz Zgółka).

51. Hubert Piechocki, Jak mówiq harcerze, czyli leksyka gwary środowiskowej harcerzy (prof. dr hab. Tadeusz Zgółka).

52. Izabela Piotrowska, Stownictwo $i$ frazeologia życia towarzyskiego w prasie kobiecej (prof. dr hab. Anna Piotrowicz).

53. Anna P is a rek, Btędyjęzykowewwypracowaniach uczniów klas czwartych (prof. dr hab. Anna Piotrowicz).

54. Katarzyna Piskorska, Porównania $w$,Listach” Stefana Żeromskiego (prof. dr hab. Anna Piotrowicz).

55. Beata Pomykalska, Stownictwo tematyczne $w$ osiemnastowiecznej pracy Krzysztofa Kluka „O rolnictwie" (prof. dr hab. Jerzy Sierociuk).

56. Małgorzata Pomykała, Zapożyczenia angielskie $w$ języku młodzieżowym na podstawie prasy mto- 
dzieżowej (prof. dr hab. Stanisław Mikołajczak).

57. Anna Robak, Sposoby wyrażania złości $w$ polskiej prozie psychologicznej (na przykładzie „Cudzoziemki" Marii Kuncewiczowej oraz „Zazdrości i medycyny” Michała Choromańskiego) (prof. dr hab. Anna Piotrowicz).

58. Emilia Teresa Rogacka, Grzecznościowe akty mowy $w$ komunikacji internetowej (prof. dr hab. Anna Piotrowicz).

59. Anna R o r a t, Językowy obraz świata $w$ czasopismach motocyklowych z lat 2002-2007 (prof. dr hab. Stanisław Mikołajczak).

60. Anna Sabik, Dyskurs mody w czasopiśmie „Dziewczyna” (prof. $\mathrm{dr}$ hab. Andrzej Sieradzki).

61. Krzysztof Skowroński, Obraz świata zawarty z tekstach artystów polskiego hip-hopu (prof. dr hab. Tadeusz Zgółka).

62. Aleksandra Stachura, Stownictwo dotyczace życia towarzyskiego w „Lalce” Bolestawa Prusa (prof. dr. hab. Alicja Pihan-Kijasowa).

63. Anna Stakaeva, Koncepty, ,stońce”, , księżyc”, ,gwiazdy” we frazeologizmach polskich $i$ rosyjskich (prof. dr hab. Alicja Pihan-Kijasowa).

64. Radosław Staniszczak, Analiza leksykalna, sktadniowa i stylistyczna nagłówków stosowanych na stronach sportowych dzienników ogólnopolskich na przyktadzie ,"Gazety Wyborczej” oraz „Faktu” (prof. dr hab. Stanisław Mikołajczak).

65. Monika Stępniak, Weź kredyt $w$ naszym banku, czyli perswazja jezykowa $w$ reklamie (prof. dr hab. Tadeusz Zgółka).

66. Marta Anna Sulińska, Świadomość językowa Polaków w Szwecji.
Studium pragmalingwistyczne (prof. dr hab. Anna Piotrowicz).

67. Ewelina Sworek, Językowy obraz tańca brzucha - na przykładzie stron internetowych tancerek brzucha (prof. dr hab. Stanisław Mikołajczak).

68. Barbara Szla chetka, Polityka stowami Tadeusza Cymańskiego, czyli studium idiolektu (prof. dr hab. Tadeusz Zgółka).

69. Natalia Cecylia Sznajdrowicz, Polszczyzna konsumpcyjna zwiazana $z$ promowaniem zdrowia (na podstawie czasopisma ,Moda na Zdrowie”) (prof. dr hab. Anna Piotrowicz).

70. Magdalena Szulc, Stownictwo wartościujace $w$ stużbie reklamy na przyktadach reklam z poczatku XX wieku $i$ wspótczesnych (prof. dr hab. Stanisław Mikołajczak).

71. Marzena Tabaczyńska, Polski dyskurs polityczny $w$ ksiażkach Tomasza Lisa (prof. dr hab. Anna Piotrowicz).

72. Łucja Umińska, Zapożyczenia $z$ języka rosyjskiego $w$ powojennych słownikach wyrazów obcych (prof. dr hab. Alicja Pihan-Kijasowa).

73. Dagmara Walc zyk, Świat Grzegorza Turnaua opisany stowami (prof. dr hab. Tadeusz Zgółka).

74. Kamila Walkowiak, Nowe nazwy zawodów w polszczyźnie XXI wieku (na przykładzie ogłoszeń prasowych $i$ internetowych) (prof. dr hab. Anna Piotrowicz).

75. Agnieszka Wawrzyniak, Błędy poprawione, czyli o sposobach poprawiania pisemnych części egzaminów certyfikatowych (prof. dr hab. Tadeusz Zgółka).

76. Julia Wieczorek, Stownictwo $i$ frazeologia życia towarzyskiego współczesnej młodzieży (prof. dr hab. Anna Piotrowicz). 
77. Weronika Wieczorek, Odchodzqce stownictwo kulinarne (prof. $\mathrm{dr}$ hab. Anna Piotrowicz).

78. Barbara Wilczyńska, Pola semantyczne $w$ języku żotnierzy (prof. dr hab. Tadeusz Zgółka)

79. Kinga Wiśniewska, Kobieta fatalna $i$ macho - czyli emocjonalne określenia kobiet i mężczyzn we współczesnej polszczyźnie (prof. dr hab. Tadeusz Zgółka).

80. Beata Wojewoda, Obraz mężczyzny $w$,Rodzinie Połanieckich” $i$, Bez dogmatu” Henryka Sienkiewi$c z a$ (prof. dr hab. Andrzej Sieradzki).

81. Arkadiusz W szędybył, Stownictwo profesjonalne $w$,Tygodniku Rolniczym" z lat 2007-2010 (prof. dr hab. Stanisław Mikołajczak).

82. Marta Zydlewicz, Terminy $z$ zakresu chemii z komponentem nazwy własnej $w$ podręcznikach chemii (prof. dr hab. Stanisław Mikołajczak).

Sporządziła Agnieszka Krygier-Łaczkowska 